\title{
RESEARCH ARTICLE \\ The effects of local and systemic inflammatory status on iron metabolism and lipid profile in calves
}

\author{
(1) \\ Uğur Aydoğdu ${ }^{1 *}$, İbrahim Yurdakul ${ }^{2}$ \\ ${ }^{1}$ Balıkesir University, Veterinary Faculty, Department of Internal Medicine, Balıkesir, Turkey \\ ${ }^{1}$ Sivas Cumhuriyet University, Veterinary Faculty, Department of Surgery, Sivas, Turkey
}

Received:07.02.2020, Accepted: 04.05.2020

*ugur.aydogdu@balikesir.edu.tr

\section{Buzağılarda lokal ve sistemik inflamatuar durumun demir metabolizması ve lipit profili üzerine etkileri}

Eurasian J Vet Sci, 2020, 36, 2, 121-126

DOI: $10.15312 /$ EurasianJVetSci.2020.269

Öz

Amaç: Bu çalışmanın amacı, buzağılarda lokal ve sistemik inflamatuar durumun demir metabolizması ve lipit profili üzerine etkilerinin belirlenmesidir.

Gereç ve Yöntem: Çalışmada farklı ırk ve cinsiyette 39 hasta ve 17 sağlıklı olmak üzere toplam 56 buză̆ı kullanıldı. Hasta buzağılar lokal ( 8 omfalit ve 11 artritis) ve sistemik (10 enterit ve 10 pnömoni) yangı olmak üzere 2 gruba ayrıldı. Tüm buzağıların rutin klinik muayeneleri yapıldıktan sonra kan analizleri için $8 \mathrm{ml}$ kan alındı ve biyokimyasal analizleri yapıldı.

Bulgular: Lokal ve sistemik yangılı buzağılarda serum demir, total kolesterol (TC), yüksek dansiteli lipoprotein (HDL) ve albümin düzeylerinin kontrol grubuna göre önemli düzeyde ( $p<0.05)$ düştüğü tespit edildi. Serum üre ve kreatinin düzeyleri ise sistemik yangılı buzağılarda kontrol grubuna göre önemi düzeyde $(\mathrm{p}<0.05)$ yüksekti.

Öneri: Sonuç olarak, düșük demir, total kolesterol, HDL ve albümin düzeylerinin buzağılarda lokal ve sistemik yangıyı işaret edebileceği değerlendirildi.

Anahtar kelimeler: Yangl, demir, lipit profili, buzağı
Abstract

Aim: The aim of this study was to determine the effects of local and systemic inflammatory status on iron metabolism and lipid profile in calves.

Materials and Methods: A total of 56 calves, 39 sick and 17 healthy, were used in the study in different races and genders. The sick calves were divided into two groups as local (8 omphalitis and 11 arthritis) and systemic (10 enteritis and 10 pneumonia) inflammations. After routine clinical examinations of all the animals were performed, $8 \mathrm{ml}$ of blood was taken for blood analysis and biochemical analyses were performed.

Results: Serum iron, total cholesterol (TC), high density lipoprotein (HDL) and albumin levels were significantly ( $p$ $<0.05$ ) lower in calves with local and systemic inflammation compared to the control group. Serum urea and creatinine levels were significantly $(\mathrm{p}<0.05)$ higher in calves with systemic inflammation compared to the control group.

Conclusion: As a result, it was evaluated that low iron, total cholesterol, HDL and albumin levels may indicate to local and systemic inflammation in calves.

Keywords: Inflammation, iron, lipid profile, calf 


\section{Introduction}

Calf diseases have a major impact on the economic viability of cattle operations, due to the direct costs of calf losses and treatment and long-term effects on performance (Donovan et al 1998, Lorenz et al 2011). The most common causes of morbidity and mortality in the calves are diarrhea and, less frequently, pneumonia (Astiz et al 2018). Diseases such as arthritis and omphalitis are also responsible for morbidity and mortality (Bozukluhan et al 2017, Constable et al 2017). Studies are underway to prevent morbidity and mortality, to identify diseases and to determine pathogenesis during this period.

Biomarkers are used for the early detection of diseases in humans and animals and also for the evaluation of prognosis (Basoglu et al 2014, Aygun and Yildiz 2018, Basoglu at al 2018, Yildız et al 2018). Among these biomarkers, iron (Fe) metabolism and changes in lipid profile are also important. It has been reported that in different inflammatory processes, significant reductions in Fe levels were reported in humans (Srinivas et al 1988, Sipahi et al 2004), calves (Aydoğdu et al 2018) and dogs (Torrente et al 2015). Endotoxemia is also reported to cause negative mineral balance (reduction in iron and zinc levels). As a part of the acute phase response, the minerals help to clear the body's bacteria in the bacterial invasion. In the acute phase response, there is a decrease in serum iron concentration during fever (Constable et al 2017). In humans (Barati et al 2011) and animals (Civelek et al 2007, Bozukluhan et al 2017, Aydogdu et al 2018), infection and inflammation have been reported to cause significant changes in plasma lipid and lipoprotein concentration, composition, and function. Many of these changes have been shown to be induced by cytokines released during infections and inflammations (Lekkou et al 2014). Circulating lipoproteins play a very important role in the pathophysiology of infectious diseases. In most studies in human patients with infection and inflammation have reported decreased serum levels of TC, HDL and low-density lipoprotein (LDL), and increased triglyceride (TG). It was also stated that these changes were independent of the underlying disease or infectious agents (Alvarez and Ramos 1986, Barati et al 2011, Fitrolaki et al 2016, Bermudes et al 2017). Although there are studies on Fe and lipid metabolism in some infections in the calves, there are no studies that are evaluated together in different types of infections.

In this study, we aimed to evaluate whether it has any role of serum Fe level and lipid profile in the pathogenesis of local or systemic inflammation in calves.

\section{Material and Methods}

In this study, a total of 56 calves, 39 sick calves (2-60 days old) with different infections and 17 healthy calves (7-60 days old) in different races and genders were used as animal material brought to for the examining and treatment to Sivas Cumhuriyet University Faculty of Veterinary Medicine Animal Hospital. For control purposes, the calves were obtained from several different cattle farms from the same area. The control group was included in the study of those who did not have any infectious / inflammatory condition by making health checks on the animals. The sick calves were divided into two groups as local (8 omphalitis and 11 arthritis) and systemic (10 enteritis and 10 pneumonia) inflammation. The calves with more than one different infection were not included in the study.

After the clinical examination of all the calves was done, $8 \mathrm{ml}$ of blood was taken from vena jugularis to without anticoagulant tubes for blood analysis. Blood samples were kept at room temperature and allowed to clot, then centrifuged at $5000 \mathrm{rpm}$ for $5 \mathrm{~min}$ to remove the serum and stored at -80 ${ }^{\circ} \mathrm{C}$ until analyzed. The concentrations of $\mathrm{Fe}$, unsaturated iron binding capacity (UIBC), total iron binding capacity (TIBC), TC, HDL, LDL, TG, very low density lipoprotein (VLDL), urea, creatinine and albumin in serum of the calves were determined with an auto analyzer (XL-1000, Erba Lachema, Brno, Czech Republic) using commercial kits.

\section{Statistics analysis}

The data were presented as mean and the standard error of mean. Kolmogrov-Smirnov test was performed to determine the normal distribution of data. Differences between the groups were determined by one-way ANOVA and Tukey test for variables with a normal distribution (UIBC, TIBC, total cholesterol, HDL, LDL and albumin) whilst for variables that do not show normal distribution (Iron, triglyceride, VLDL, urea and creatinine) were analyzed with Kruskal Wallis. $\mathrm{P}<0.05$ was considered statistically significant. Statistical analyses were determined using the SPSS software program.

\section{Results}

All of the calves involved in the study were $\leq 60$ days old and had not been pre-weaned. In the calves with arthritis, typical clinical signs such as lameness in varying degrees, the pain in palpation and manipulation of the relevant joint, local temperature increase, joint swelling and sensitivity at varying levels and decreased appetite, weakness and fever in a few cases were determined. Depending of the severity of the lameness, animal's stance was changed. In radiologically, the opacity increase and joint tension due to increased purulence or increased purulence with gas in certain cases were detected. In radiological examination, the articular destruction, intraarticular narrowing and degeneration on joint surface in some cases were determined. 


\begin{tabular}{|c|c|c|c|}
\hline Parameters & $\begin{array}{l}\text { Systemic inflammation } \\
\qquad \mathrm{n}=20\end{array}$ & Local inflammation $n=19$ & $\begin{array}{c}\text { Control } \\
\text { group } \\
\mathrm{n}=17\end{array}$ \\
\hline Iron $(\mu \mathrm{g} / \mathrm{dl})$ & $72,53 \pm 7,25^{b}$ & $65,25 \pm 4,56^{b}$ & $141,82 \pm 12,57^{\mathrm{a}}$ \\
\hline $\mathrm{UIBC}(\mu \mathrm{g} / \mathrm{dl})$ & $405,45 \pm 34,68$ & $390,24 \pm 25,91$ & $335,69 \pm 24,66$ \\
\hline TIBC ( $\mu \mathrm{g} / \mathrm{dl})$ & $478,06 \pm 30,85$ & $455,61 \pm 26,66$ & $477,65 \pm 22,71$ \\
\hline Total cholesterol (mg/dl) & $43,55 \pm 3,67^{b}$ & $58,76 \pm 5,90^{\mathrm{b}}$ & $82,47 \pm 5,12^{\mathrm{a}}$ \\
\hline HDL (mg/dl) & $31,99 \pm 2,48^{b}$ & $41,00 \pm 4,37^{b}$ & $60,08 \pm 3,60^{\mathrm{a}}$ \\
\hline LDL (mg/dl) & $10,42 \pm 1,75$ & $11,00 \pm 1,97$ & $15,67 \pm 1,86$ \\
\hline Triglyceride (mg/dl) & $16,06 \pm 2,66$ & $29,06 \pm 5,60$ & $31,24 \pm 4,62$ \\
\hline VLDL (mg/dl) & $3,40 \pm 0,55$ & $5,68 \pm 1,09$ & $6,18 \pm 0,91$ \\
\hline Urea (mg/dl) & $108,77 \pm 21,35^{\mathrm{a}}$ & $26,29 \pm 3,67^{b}$ & $14,26 \pm 0,63^{b}$ \\
\hline Creatinine (mg/dl) & $2,18 \pm 0,36^{a}$ & $0,94 \pm 0,05^{\mathrm{b}}$ & $1,06 \pm 0,03^{b}$ \\
\hline Albumin (g/dl) & $2,56 \pm 0,08^{b}$ & $2,26 \pm 0,05^{c}$ & $2,82 \pm 0,03^{\mathrm{a}}$ \\
\hline
\end{tabular}

UIBC: unsaturated iron binding capacity, TIBC: total iron binding capacity, HDL: high-density lipoprotein, LDL: low-density lipoprotein, VLDL: very low density lipoproteins Different letters in the same rows $(a-c)$ are statistically significant $(p<0.05)$.

In the calves with omphalitis, in clinically examination, there was swelling, pain, redness and increased temperature in the um bilicus of calves with omphalitis. It was also seen that some cases were fistulized. In cases where lesions such as omphalitis and omphalophilebitis were together inflammatory signs such as pain and temperature were also seen. In the calves with enteritis, diarrhea continuing 1-4 days, dehydration, absence or decrease in suckling reflex, depression, weakness, hypothermia, standing difficulty or sternal position were observed. It was observed that the diarrhea was watery, malodorous and bloody in some calves. In the calves with pneumonia, tachypnea, dyspnea, the trachea and larynx are susceptible, cough and mucous and/or mucopurulent nasal discharge, absence of suction reflex and fever were observed.

Changes in iron metabolism, lipid profile and biochemical parameters of calves with local and systemic inflammation and healthy calves are given in Table 1 . Serum iron, total cholesterol, HDL and albumin levels were significantly $(\mathrm{p}<0.05)$ lower in calves with local and systemic inflammation compared to the control group. In addition, albumin level was significantly $(\mathrm{p}<0.05)$ lower in calves with local inflammation compared to calves with systemic inflammation. Serum urea and creatinine levels were significantly $(\mathrm{p}<0.05)$ higher in the calves with systemic inflammation compared to the control group.

\section{Discussion}

Various diseases, such as omphalitis, arthritis, pneumonia and enteritis, that cause inflammation are frequently observed in the calves. Among these diseases diarrhea, particularly in the neonatal period, is much more frequently confronted than other diseases. These illnesses are responsible for serious economic losses, causing morbidity and mortality (Lorenz et al 2011, Bozukluhan et al 2017, Constable et al 2017, Astiz et al 2018). Studies on the prevention, pathogenesis and treatment of these diseases are continuing and efforts are being made to minimize these economic losses by minimizing morbidity and mortality.

Inflammatory clinical conditions affect the lipid profile. In human patients with sepsis and SIRS, an increase in TG levels and a decrease in TC, HDL and LDL levels are observed. These changes in the lipid profile during infection are most evident in the first $72 \mathrm{~h}$ (Alvarez and Ramos 1986, Barati et al 2011, Cherayil 2011). Many studies in human patients with infection have reported decreased serum levels of TC, HDL and LDL, and increased TG. These changes were reported to be independent of underlying disease or infectious agents (Fitrolaki et al 2013, Fitrolaki et al 2016, Bermudes et al 2017). It has been reported that diarrhoea (Bozukluhan et al 2017), pneumonia (Joshi et al 2015) and sepsis (Aydogdu et al 2018) have been shown to significantly reduce TC, HDL and LDL levels in calves. 
El-Bahr and El-Deeb (2013) also reported that pneumonia causes low TC, HDL and LDL levels in water buffalo calves, and that these parameters may be biomarkers that can be used in the diagnosis of bronchopneumonia. Nassaji and Ghorbani (2012) reported that acute bacterial infections are associated with low TC and HDL levels and that plasma lipid levels may serve as a marker of acute bacterial infections. In this study, serum TC and HDL levels were significantly (p $<0.05$ ) lower in calves with local and systemic inflammation compared to the control group. In addition, TC and HDL levels of the calves with systemic inflammation were lower than the calves with local inflammation, but no statistical difference was detected. The findings of the study confirm the studies showing that TC and HDL levels decrease in case of inflammation. The present study showed that low TC and HDL levels may be indicative of both local and systemic inflammation in calves. Pathological changes during the course of local or systemic inflammatory process appear to affect TC and HDL levels at different levels. This may be related to the effects of systemic inflammation on other tissue/organs (Aydogdu et al 2018, Aygun and Yildiz 2018, Ylldız et al 2018) and energy metabolism (Basoglu et al. 2014, Basoglu et al 2018).

Iron metabolism is also affected by acute phase reactions. Plasma or serum Fe concentrations decrease as part of the acute phase response (Constable et al 2017). The increase in Fe-binding plasma proteins such as lactoferrin and the increase in Fe uptake of macrophages decrease plasma free Fe concentration and inhibit bacterial growth (Castellheim et al 2009). It has been reported that there is a decrease in Fe level in acute infected humans and this decrease is observed from the first day (Srinivas et al 1988, Sipahi et al 2004). It is also stated that Fe levels decrease in human with sepsis and SIRS and it may be useful to monitor Fe levels in these patients (Shanbhogue and Paterson 1990, Ayoglu et al 2016 ). Aydoğdu et al (2018) reported that serum Fe levels significantly decreased in calves with SIRS and that serum Fe levels could be a useful parameter in determining the inflammatory response. Baydar and Dabak (2014) stated that serum Fe levels in cattle with reticuloperitonitis traumatica and mastitis could be a useful parameter for determining of the inflammation. A significant decrease in serum Fe levels has been reported in horses in response to intra-articular lipopolysaccharide injection (Andreassen et al 2017). Torrente et al (2015) reported that plasma iron concentration was significantly lower in dogs with systemic inflammation compared to dogs with both healthy and local inflammation and hypoferremia in dogs is a sensitive marker of systemic inflammation. In this study, serum Fe level was significantly ( $p<0.05$ ) lower in calves with local and systemic inflammation compared to the control group. However, there was no difference in serum Fe level in calves with local and systemic inflammation. The results of our study were found not to be similar to Torrente et al (2015). In this study, unlike Torrente et al (2015), it has been determined that low serum Fe concentration can indicate both local and systemic inflammation in calves.

Acute phase response is a series of physiological changes that occur in response to stimuli such as trauma, infection, malignancy and immunological disorders. The acute phase response is initiated and coordinated by cytokines (Eckersall and Bell 2010, Jain et al 2011, Kırbas et al 2019). Albumin is a negative acute phase protein and its concentration decreases by more than $25 \%$ during the inflammatory response (Schmidt and Eckersall 2015). It is stated that in dogs and cats, reduced albumin levels in the event of inflammation or infection may provide an estimate of the acute phase reaction (Ceron et al 2005). Torrente et al (2015) reported that the plasma albumin concentration in dogs with SIRS was inversely corralated to the severity of inflammation. Despite the fact that the albumin is now easy and cheap to measure, it has low clinical value in the diagnosis and monitoring of inflammation (Ceron et al 2005). In this study, serum albumin level was significantly ( $p<0.05$ ) lower in calves with local and systemic inflammation compared to the control group. In addition, interestingly, the albumin level of calves with local inflammation was lower than that of the calves with systemic inflammation. This may be due to the fact that half of the calves with systemic inflammation are diarrhea calves. Because, albumin levels higher than the value that should be measured due to dehydration in calves with diarrhea can be determined (Guzelbektes et al 2007). Although low albumin level may to indicate inflammation, its diagnostic value is questionable due to its low clinical value.

Multiple organ failure can be observed during the course of systemic inflammation such as sepsis and this may cause deaths (Gupta and Jonas 2006). It has been reported that high serum urea nitrogen concentrations are also observed in acute endotoxemia and this increase is a reflection of the decrease in glomerular filtration (Constable et al 2017). Aydogdu et al (2018) also found that serum urea nitrogen and creatinine levels significantly increased in calves with sepsis compared to healthy ones. In this study, serum urea and creatinine levels were found to be significantly $(\mathrm{p}<0.05)$ higher in the calves with systemic inflammation compared to the control group, but no difference was found in calves with local inflammation. This increase in calves with systemic inflammation may possibly be associated with a decrease in glomerular filtration. In addition, our study results showed that it may be beneficial to evaluate renal functions during systemic inflammation in calves.

\section{Conclusion}

In conclusion, it was determined that local and systemic inflammation in calves caused a decrease in serum Fe, TC, HDL and albumin levels. Furthermore, the results of this study 
show that serum Fe, TC and HDL concentrations may be appropriate tests to detect the inflammatory response in calves. It has been also observed that changes in Fe metabolism and lipid profile may play an important role in the pathophysiology of diseases and require different advanced studies.

\section{Conflict of Interest}

The authors did not report any conflict of interest or financial support.

\section{Funding}

During this study, any pharmaceutical company which has a direct connection with the research subject, a company that provides and / or manufactures medical instruments, equipment and materials or any commercial company may have a negative impact on the decision to be made during the evaluation process of the study or no moral support.

\section{References}

Alvarez C, Ramos A, 1986. Lipids, lipoproteins, and apoproteins in serum during infection. Clin Chem, 32, 142-145.

Andreassen SM, Vinther AML, Nielsen SS, Andersen PH, et al., 2017. Changes in concentrations of haemostatic and inflammatory biomarkers in synovial fluid after intra-articular injection of lipopolysaccharide in horses. BMC Vet Res, 13, 182.

Astiz S, Gonzalez-Bulnes A, Elvira-Partida L, Perez-Villalobos $\mathrm{N}$, et al., 2018. Bovine Neonatology, https://www.eolss. net/sample-chapters/C10/E5-15A-33.pdf Available: June 17, 2018.

Aydogdu U, Coskun A, Yildiz R, Guzelbektes H, et al., 2018. Clinical importance of lipid profile in neonatal calves with sepsis. J Hellenic Vet Med Soc, 69, 1189-1194.

Aydoğdu U, Coşkun A, Yıldız R, Güzelbekteş H, et al., 2018. Sistemik yangısal cevap sendromlu buzağılarda hematolojik parametreler ve serum demir düzeyindeki değişimler. Eurasian J Vet Sci, 34, 56-59.

Aygun 0, Yildiz R, 2018. Evaluation of thrombomodulin and pentraxin-3 as diagnostic biomarkers in calves with sepsis. Vet Med, 63, 313-320.

Ayoglu H, Sezer U, Akin M, 2016. Selenium, copper, zinc, iron levels and mortality in patients with sepsis and systemic inflammatory response syndrome in Western Black Sea Region, Turkey. J Pak Med Assoc, 66, 447-452.

Barati M, Nazari MZ, Taher MT, Farhadi N, 2011. Comparison of lipid profile in septic and non-septic patients. Iran J Clin Infect Dis, 6, 144-147.

Basoglu A, Baspinar N, Tenori L, Hu X, et al., 2014. NMR based metabolomics evaluation in neonatal calves with acute diarrhea and suspected sepsis: A new approach for biomarker/s. Metabolomics, 4, 134.

Basoglu A, Sen I, Meoni G, Tenori L, et al., 2018. NMR-Based plasma metabolomics at set intervals in newborn dairy calves with severe sepsis. Mediators Inflamm, 2018, 8016510.

Baydar E, Dabak M, 2014. Serum iron as an indicator of acute inflammation in cattle. J Dairy Sci, 97, 222-228.

Bermudes ACG, Carvalho WB, Zamberian P, Muramoto G, et al., 2017. Changes in lipid metabolism in paediatric patients with severe sepsis and septic shock. Crit Care Med, 13, 688-691.

Bozukluhan K, Merhan O, Gokce HI, 2017. Alterations in lipid profile in neonatal calves affected by diarrhea. Vet World, 10, 786-789.

Castellheim A, Brekke OL, Espevik T, Harboe M, et al., 2009. Innate immune responses to danger signals in systemic inflammatory response syndrome and sepsis. Scand J Immunol, 69, 479-491.

Ceron JJ, Eckersall PD, Martýnez-Subiela S, 2005. Acute phase proteins in dogs and cats: current knowledge and future perspectives. Vet Clin Pathol, 34, 85-99.

Cherayil BJ, 2011. The role of iron in the immune response to bacterial infection. Immunol Res, 50, 1-9.

Civelek T, Kav K, Camkerten I, Celik HA, et al., 2007. Effects of bacterial pneumonia in neonatal calves on serum lipids. Bull Vet Inst Pulawy, 51, 503-507.

Constable PD, Hinchcliff KW, Done SH, Grünberg W, 2017. Veterinary Medicine. A textbook of the diseases of cattle, horses, sheep, pigs and goats. 11th ed, Saunders Ltd., Missouri.

Donovan GA, Dohoo IR, Montgomery DM, Bennett FL, 1998. Calf and disease factors affecting growth in female Holstein calves in Florida, USA. Prev Vet Med, 33, 1-10.

Eckersall PD, Bell R, 2010. Acute phase proteins: Biomarkers of infection and inflammation in veterinary medicine. Vet J, 185, 23-27.

El-Bahr SM, EL-Deeb WM, 2013. Acute phase proteins, lipid profile and proinflammatory cytokines in healthy and bronchopneumonic water buffalo calves. Am J Biochem Biotechnol, 9, 34-40.

Fitrolaki DM, Dimitriou H, Kalmanti M, Briassoulis G, 2013. CD64-Neutrophil expression and stress metabolic patterns in early sepsis and severe traumatic brain injury in children. BMC Pediatr, 13, 31.

Fitrolaki MD, Dimitriou H, Venihaki M, Katrinaki M, et al., 2016. Increased extracellular heat shock protein 90a in severe sepsis and SIRS associated with multiple organ failure and related to acute inflammatory-metabolic stress response in children. Medicine, 95, e 4651.

Gupta S, Jonas M, 2006. Sepsis, septic shock and multiple organ failure. Anaesthesia and Intensive Care Medicine, 7, 143-146.

Guzelbektes H, Coskun A, Sen I, 2007. Relationship between the degree of dehydration and the balance of acid-based changes in dehydrated calves with diarrhoea. Bull Vet Inst Pulawy, 51, 83-87.

Jain S, Gautam V, Naseem S, 2011. Acute-phase proteins: As diagnostic tool. J Pharm Bioallied Sci, 3, 118-27.

Joshi V, Gupta VK, Dimri U, Mandal RSK, et al., 2015. Serum 
lipid profile in bacterial Bovine Respiratory Disease (BRD) affected calves. Intas Polivet 16, 187-88.

Kirbas A, Kandemir FM, Celebi D, Hanedan B, et al., 2019. The use of inflammatory markers as a diagnostic and prognostic approach in neonatal calves with septicaemia. Acta Vet Hung, 67 (3), 360-376.

Lekkou A, Mouzaki A, Siagris D, Ravani I, et al., 2014. Serum lipid profile, cytokine production, and clinical outcome in patients with severe sepsis. J Crit Care, 29, 723-727.

Lorenz I, Mee JF, Earley B, More SJ, 2011. Calf health from birth to weaning. I. General aspects of disease prevention. Ir Vet J, 64, 10.

Nassaji M, Ghorbani R, 2012. Plasma lipid levels in patients with acute bacterial infections. Turk J Med Sci, 42, 465-469.

Schmidt EMS, Eckersall PD, 2015. Acute phase proteins as markers of infectious diseases in small animals. Acta Vet Beograd 65, 149-161.

Shanbhogue LK, Paterson N, 1990. Effect of sepsis and surgery on trace minerals. J Parenter Enteral Nutr, 14, 287289.

Sipahi T, Köksal T, Tavil B, Akar N, 2004. The effects of acute infection on hematological parameters. Pediatr Hematol Oncol J, 21, 511-518.

Srinivas U, Braconier JH, Jeppsson B, Abdulla M, et al., 1988. Trace element alterations in infectious diseases. Scand J Clin Lab Invest, 48, 495-500.

Torrente C, Manzanilla EG, Bosch L, 2015. Plasma iron, C-reactive protein, albumin, and plasma fibrinogen concentrations in dogs with systemic inflammatory response syndrome. J Vet Emerg Crit Care (San Antonio), 25, 611619.

Yıldız R, Beslek M, Beydilli Y, Özçelik M, et al., 2018. Evaluation of platelet activating factor in neonatal calves with sepsis. Vet Hekim Der Derg, 89, 66-73.

\section{Author Contributions}

Motivation / Concept: Uğur Aydoğdu, İbrahim Yurdakul Design: Uğur Aydoğdu, İbrahim Yurdakul

Control/Supervision: Uğur Aydoğdu, İbrahim Yurdakul Data Collection and / or Processing: Uğur Aydoğdu, İbrahim Yurdakul

Analysis and / or Interpretation: Uğur Aydoğdu, İbrahim Yurdakul

Literature Review: Uğur Aydoğdu, İbrahim Yurdakul Writing the Article: Uğur Aydoğdu, İbrahim Yurdakul Critical Review: Uğur Aydoğdu, İbrahim Yurdakul 